\title{
PKM Kelompok Usaha Pembuatan Manisan Nangka di Desa Selorejo-Kucur Kecamatan Dau Kabupaten Malang Provinsi Jawa Timur
}

\author{
Budi Santosa $^{1}$, Lorine Tantalu ${ }^{2}$ dan Rozana ${ }^{3}$ \\ 1,2,3 Program Studi Industri Pertanian, Fakultas Pertanian, \\ 1,2,3 Universitas Tribhuwana Tunggadewi \\ e-mail: budi.unitri@gmail.com
}

\begin{abstract}
Abstrak
Program pemberdayaan masyarakat ini bertujuan untuk meningkatkan kualitas produk manisan nangka kering yang dihasilkan oleh industri berskala kecil yakni CV. Pia Toulip yang bertempat di Desa Selorejo-Kucur Kecamatan Dau Kabupaten Malang Provinsi Jawa Timur. Strategi yang digunakan guna mencapai tujuan tersebut adalah dengan melalui beberapa kegiatan diantaranya kegiatan pendampingan dalam perbaikan penanganan bahan baku, pendampingan proses produksi dan proses pengemasan, pendampingan penyusunan SOP, serta pendampingan kegiatan pemasaran yang bekerjasama dengan CV. Mitra Market. Kegiatan yang dicapai adalah peningkatan keterampilan dalam membuat manisan serta kualitas produk yang sesuai dengan standar mutu SNI manisan kering berupa warna produk yang tidak mengalami browning. Produk yang dihasilkan berwarna kuning keemasan sebagai hasil dari pengeringan dengan pengelolaan suhu yang baik melalui penerapan alat pengering. Pendampingan kegiatan pengemasan juga dilakukan dengan memperhatikan kelayakan usaha. Kegiatan pemasaran dilakukan dengan melibatkan CV. Mitra Market selaku pihak penjual yang sebelumnya dilakukan uji pasar terkait kualitas produk. Perlu dilakukan pendampingan lebih lanjut khususnya pada CV. Pia Toulip.
\end{abstract}

Kata kunci : Manisan Nangka Kering; CV Toulip; CV.Mitra Market; Program Kemitraan Masyarakat

\begin{abstract}
This community empowerment program aims to improve the quality of dried jackfruit products produced by small-scale industries, namely CV. Pia Toulip, located in Selorejo-Kucur Village, Dau District, Malang Regency, East Java Province. The strategy used to achieve these objectives is through several activities including mentoring activities in improving the handling of raw materials, mentoring the production process and packaging process, mentoring the preparation of SOPs, and mentoring marketing activities in collaboration with CV. Market Partners. The activity achieved was an increase in skills in making sweets and product quality in accordance with SNI quality standards for dried sweets in the form of color products that did not experience browning. The resulting product is golden yellow as a result of drying with good temperature management through the application of dryers. Assistance in packaging activities is also carried out by taking into account business feasibility. Marketing activities are carried out by involving CV. Market partners as sellers who previously conducted market tests related to product quality. Further assistance is needed, especially on the CV. Pia Toulip.
\end{abstract}

Keywords : Dried jackfruit products; CV Toulip; CV. Mitra Market 


\section{PENDAhuluan}

Buah nangka merupakan komoditas hortikultura yang memiliki jumlah produksi tinggi khususnya di Jawa Timur dengan total produksi mencapai 52 ton per tahun. Aroma dan rasa buah nangka menjadi daya tarik tersendiri yang banyak diminati oleh masyarakat dari berbagai kalangan. Disisi lain, buah nangka juga salah satu jenis buah yang mudah sekali membusuk setelah dipanen ${ }^{1}$. Untuk menghindari kerusakan sekaligus meningkatkan nilai gizi dan daya jual buah nangka, diperlukan upaya penerapan teknologi tepat guna. Manisan nangka adalah salah satu dari jenis pengolahan buah nangka dengan penerapan teknologi pengeringan dan penambahan bahan kimia yang memiliki beberapa manfaat yaitu memperpanjang masa simpan, menguatkan aroma dan rasa, meningkatkan nilai gizi, serta meningkatkan nilai jual buah nangka tersebut ${ }^{2}$.

CV Toulip sebagai mitra yang memproduksi manisan nangka memiliki masalah dalam hal mutu produk manisan, yakni warna produk yang mengalami browning dan belum memiliki kemasan standar. Solusi yang ditawarkan atas semua permasalahan yang dihadapi oleh mitra akan disesuaikan dengan tujuan Program Kemitraan Masyarakat (PKM) ini yaitu:1).Pendampingan proses perbaikan pembuatan manisan nangka melalui fasilitasi sistem rumah kaca yang dilengkapi aliran udara, 2). Penyusunan Standar Operasional dan Prosedur (SOP) dalam pembuatan manisan nangka, 3). Pendampingan proses packing dan promosi produk guna meningkatkan pemasaran manisan melalui kerjasama pemasaran dengan $\mathrm{CV}$. Mitra Market.

Luaran yang ingin dicapai adalah peningkatan mutu produk manisan nangka untuk menjadi layak jual dan memperoleh keuntungan yang bersifat berkelanjutan. Dengan demikian, kegiatan PKM kelompok usaha CV Toulip sebagai produsen manisan nangka dapat terbantu dalam memproduksi manisan nangka serta dapat menjadi produk unggulan sebagai oleh-oleh khas Malang untuk dipasarkan bersama CV Mitra Market.

\section{SUMBER INSPIRASI}

CV TOULIP merupakan industri rumah tangga yang memproduksi aneka makanan seperti pia, pie, serta minuman sari buah. Kapasitas produksi mencapai $10 \mathrm{~kg} / \mathrm{siklus} \mathrm{produksi} \mathrm{untuk} \mathrm{tiap} \mathrm{produknya.}$ Dalam rangka mengembangkan usahanya, $\mathrm{CV}$ TOULIP menambahkan varian produk baru seperti manisan. Produk manisan yang sedang dalam pengembangan ini adalah manisan nangka kering ${ }^{3}$. Buah nangka (Artocarpus heterophyllus L.) dipilih karena memiliki beberapa keunggulan, selain merupakan salah satu potensi unggulan kota Malang dengan angka produksi mencapai 752.32 ton per tahun $^{4}$. Nangka juga memiliki rasa dan aroma yang diminati oleh seluruh kalangan masyarakat domestik hingga luar kota lainnya. Nutrisi yang terkandung pada buah nangka juga cukup melimpah sehingga mengkonsumsi nangka akan mampu menekan penyakit jantung dengan menurunkan tekanan darah, mencegah anemia, meningkatkan sirkulasi darah dalam tubuh, melindungi tiroid, menjaga kesehatan tulang, serta sumber makanan yang kaya akan vitamin C dan A.

Identifikasi kondisi awal sebuah UKM perlu dilakukan untuk membandingkan kondisi setelah dilakukan pendampingan dengan kondisi awal sehingga dapat dilihat keberhasilan suatu kerja pendampingan. Identifikasi kondisi awal sebelum pendampingan dimaksudkan agar dalam pelaksanaan pendampingan, dapat dilakukan perbaikan pada halhal yang dianggap masih kurang atau belum tepat sasaran. Sebagai contoh adalah melihat aspek legal, aspek produksi, aspek pemasaran aspek keuangan, aspek SDM, dan beberapa hal lain. Kondisi ini disajikan dalam bentuk gambar maupun dinarasikan.

Permasalahan utama dalam proses produksi manisan nangka kering ini adalah mutu produk akhir 
yang dinilai masih rendah. Mutu ini digambarkan sebagai karakteristik organoleptik yang dihasilkan. Warna manisan nangka masih cokelat kehitaman, teksturnya keras dan alot, serta hilangnya aroma khas nangka.

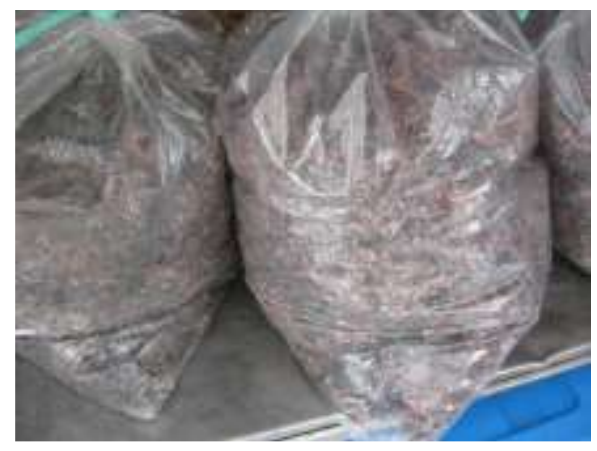

Gambar 1. Produk manisan nangka CV Toulip yang mengalami browning

Perbaikan proses produksi manisan nangka kering di CV TOULIP sangat perlu dilakukan guna menghasilkan manisan nangka kering yang bermutu tinggi sehingga diterima di pasaran. Perbaikan proses dapat dapat dimulai dari persiapan bahan (manisan nangka basah), proses pengeringan, dan pengemasan manisan. Produksi manisan nangka kering yang tepat adalah dilakukan dengan pengeringan rumah kaca sebagai upaya pemanfaat energi surya yang melimpah. Pengeringan ini maka akan dihasilkan manisan kering yang bebas dari kontaminan seperti debu jalan dan polusi kendaraan bermotor.

Salah satu faktor penting dalam proses pengeringan adalah suhu dan lama pengeringan. Suhu yang tinggi menyebabkan terjadinya proses browning $^{5}$ sehingga warna manisan yang dihasilkan akan berwarna cokelat kehitaman. Selain itu suhu tinggi juga akan menyebabkan teroksidasinya pigmen karatenoid sehingga warna kuning pada buah akan hilang. Suhu udara pengeringan yang sesuai adalah pada rentang $40-50^{\circ} \mathrm{C}^{6}$.

\section{METODE KEGIATAN}

Upaya pengembangan dan peningkatan kinerja UMKM telah dilakukan melalui banyak pendekatan.
Pendekatan pendampingan partisipatif merupakan salah satu upaya yang dapat dilakukan. Pendekatan partisipatif dipandang sebagai model pendampingan yang efektif untuk UMKM pangan. Hal tersebut dilatarbelakangi oleh beberapa faktor, yaitu: Pertama, pangan merupakan kebutuhan pokok yang pasarnya luas, namun sangat kompetitif karena banyak sekali pelaku usaha yang terjun di dalamnya. Sebuah inovasi yang muncul akan sangat cepat ditiru baik dengan modifikasi (konsep baru), maupun yang tanpa modifikasi. Jika pelaku usaha di bidang pangan tidak berinovasi, keberadaannya akan cepat tenggelam oleh pesaing-pesaing lainnya.

Oleh karena itu, dibutuhkan inovasi yang terus menerus bagi pelaku usaha pangan agar usahanya dapat terusberadaptasi dan berkembang.Kedua, pangan sebagai bahan yang dikonsumsi oleh tubuh mempersyaratkan keamanan, kehalalan, dan kehigienisan sebagai faktor kritis yang harus diperhatikan oleh produsen. Oleh karena itu, disamping aspek legal untuk usaha (seperti pelaku usaha pada umumnya), perizinan terhadap faktor kritis tersebut menjadi agenda yang harus dilakukan, dengan dimulai dengan persiapan teknis produksi. Bahkan, produk pangan fungsional seperti jamu dan produkproduk herbal, membutuhkan serangkaian uji klinis dan laboratorium yang pernyiapannya tidaklah mudah. Ketiga, produk pangan umumnya bersifat perishable (mudah rusak).

Produk-produk yang mudah rusak sangat berisiko menimbulkan kerugian bagi pelakunya. Sehingga sentuhan teknologi sangat kental, baik dalam aspek produksi, pengemasan, hingga proses distribusi. Beberapa hal yang perlu disiapkan dalam pengelolaan bisnis di bidang pangan tersebut memerlukan peranan perguruan tinggi khususnya dalam pendampingan UMKM tersebut. UMKM harus dilibatkan dalam setiap proses pengambilan keputusan, dan harus diberitahu dan diajak diskusi mengenai mengapa itu dilakukan.Tahapan kegiatan 
pendampingan sebagai upaya pemecahan masalah yang ada di mitra disajikan pada Tabel 1.

IV. KARYA UTAMA

Kegiatan pengabdian masyarakat yang bekerjasama dengan CV. Pia Toulip mampu memberikan solusi, utamanya yaitu perbaikan mutu produk manisan nangka kering. Sebelumnya, produk yang dihasilkan oleh CV. Pia Toulip sebagaoi mitra pertama memiliki warna yang kecokelatan dan tidak layak jual. Penerapan alat pengering menggunakan rumah kaca yang dilengkapi dengan exhaust ini menghasilkan suhu pengeringan kurang lebih $50^{\circ} \mathrm{C}$ disiang hari dan $37-48^{\circ} \mathrm{C}$ pada malam hari. Suhu pengeringan ini menjadikan produk manisan kering dengan optimal sehingga proses browning pada produk dapat dihindari. Disisi lain, hasil produk manisan nangka kering tersebut menjadi salah satu produk unggulan yang dipasarkan di CV. Mitra Market sebagai mitra kedua melalui metode konsinyasi, mengingat mitra kedua ini memiliki visi menjadi pusat oleh-oleh dengan produk khas Malang.

Tabel 1. Tahapan Kegiatan Pendampingan dalam Pemecahan Masalah Mitra

\begin{tabular}{|c|c|c|c|}
\hline No. & Pokok Masalah & Rencana Kerja & Output/Indikator \\
\hline \multirow[t]{4}{*}{1} & $\begin{array}{l}\text { Proses Produksi } \\
\text { (pengaturan Suhu }\end{array}$ & $\begin{array}{ll}\text { a. perbaikan sistem aliran udara didalam } \\
\text { pengering melalui pemasangan exhaust }\end{array}$ & pengering rumah kaca sudah dilengkapi exhaust fan \\
\hline & & $\begin{array}{l}\text { b. pemasangan lampu tambahan yang } \\
\text { digunakan untuk pengeringan malam hari }\end{array}$ & $\begin{array}{l}\text { pengering rumah kaca sudah dilengkapi lampu sebagai } \\
\text { sumber panas malam hari }\end{array}$ \\
\hline & & $\begin{array}{l}\text { Consultasi dan pendampingan teknologi } \\
\text { produksi dan kemasan }\end{array}$ & $\begin{array}{l}\text { kegiatan manisan nangka kering sesuai dengan SOP } \\
\text { Produksi yang telah disusun, sehingga mutu produk } \\
\text { manisan nangka tetap terjaga }\end{array}$ \\
\hline & & & $\begin{array}{l}\text { Penetapan kemasan yang memenuhi perhitungan } \\
\text { kelayakan usaha }\end{array}$ \\
\hline 2 & $\begin{array}{l}\text { Manajemen } \\
\text { Usaha }\end{array}$ & $\begin{array}{l}\text { Konsultasi dan pendampingan manajemen } \\
\text { usaha }\end{array}$ & $\begin{array}{l}\text { Dalam kegiatan usaha CV, Toulip menerapkan manajemen } \\
\text { SDM yang baik, manajemen produksi, manajemen } \\
\text { pemasaran, serta manajemen keuangan yang ditandai dengan } \\
\text { pembukuan sederhana }\end{array}$ \\
\hline 3 & $\begin{array}{l}\text { Promosi } \\
\text { Pemasaran }\end{array}$ & Fasilitasi Promosi dan Pemasaran & $\begin{array}{l}\text { Telah terjalinnya kerjasama pemasaran dengan agen pusat } \\
\text { oleh-oleh, supermarket dan outlet. }\end{array}$ \\
\hline
\end{tabular}

\section{ULASAN KARYA}

\section{Pendampingan Proses Produksi}

Kegiatan pendampingan proses perbaikan pembuatan manisan nangka kering ini dilakukan sesuai dengan rencana kerja kemitraan yaitu dengan membangun rumah kaca yang dilengkapi dengan exhaust fan yang berfungsi untuk mengurangi udara panas sehingga mengurnagi efek brwoning pada produk manisan nangka dalam proses pengeringan. Rumah kaca tersebut juga dilengkapi dengan lampu halogen yang berfungsi sebagai sumber panas untuk proses pengeringan dimalam hari. Hal ini dimaksudkan agar proses pengeringan tersebut tidak bergantung sepenuhnya oleh adanya sinar matahari. Selain pendampingan dalam penyediaan sarana demi peningkatan kualitas mutu manisan, penyusunan standar operasional dan prosedur atau SOP untuk proses penanganan bahan baku serta penanganan proses produksi manisan kering juga dilakukan. SOP tersebut disampaikan dalam presentasi oleh narasumber yang berkompeten dalam proses pengolahan pasca panen. Dalam kegiatan ini, baik pemilik CV. Toulip maupun karyawannya dilibatkan agar standar opersional prosedur yang tersusun dapat dipratekkan secara langsung (Gambar 2).

Kegiatan pendampingan tersebut diakhiri dengan serah terima rumah kaca yang diberikan kepada pihak mitra yang dalam hal ini adalah CV. Toulip (Gambar 3). Pendampingan proses pembuatan manisan nangka dilakukan sampai mendapatkan 
PKM Kelompok Usaha Pembuatan Manisan Nangka di Desa Selorejo-Kucur Kecamatan Dau Kabupaten Malang Provinsi Jawa Timur

produk yang sesuai dengan standar mutu manisan kering yang tertera pada SNI manisan buah kering SNI 01-3710-1995 dengan kadar air maksimal 31\%, tanpa pemanis buatan dan warna kuning $\operatorname{cerah}^{7}$ (Gambar 4).

\section{Manajemen Usaha}

Pendampingan manajemen usaha dilakukan dengan cara pemberian pelatihan manajemen usaha oleh narasumber terkait dalam satu hari dengan melibatkan dua mitra yakni dari CV. Toulip dan CV. Mitra Market. Hal ini dimaksudkan agar pihak produsen dapat memahami konsep pemasaran dan menghitung kelayakan usaha, memperhitungkan segala aspek produksi (Gambar 5).
Kegiatan pendampingan manajemen usaha juga memberikan pelatihan mengenai proses perhitungan sederhana tentang dampak produksi terhadap jumlah kehilangan konsumen. Hasil evaluasi program manajemen usaha ditandai dengan kemampuan mitra $\mathrm{CV}$. Toulip dalam menghitung besarnya produksi dalam memperikara jumlah keuntungan dengan jumlah konsumen yang berbeda. Hal ini dibuktikan dengan berhasilnya (100\%) dlam pengerjaan contoh perhitungan analisis kehilangan konsumen serta kelayakan usaha. Analisis keuntungan usaha harus memperhitungkan segala aspek mencakup biaya perawatan peralatan, bahan baku, upah kerja dan variabel tidak tetap seperti tarif dasar listrik ${ }^{8}$.
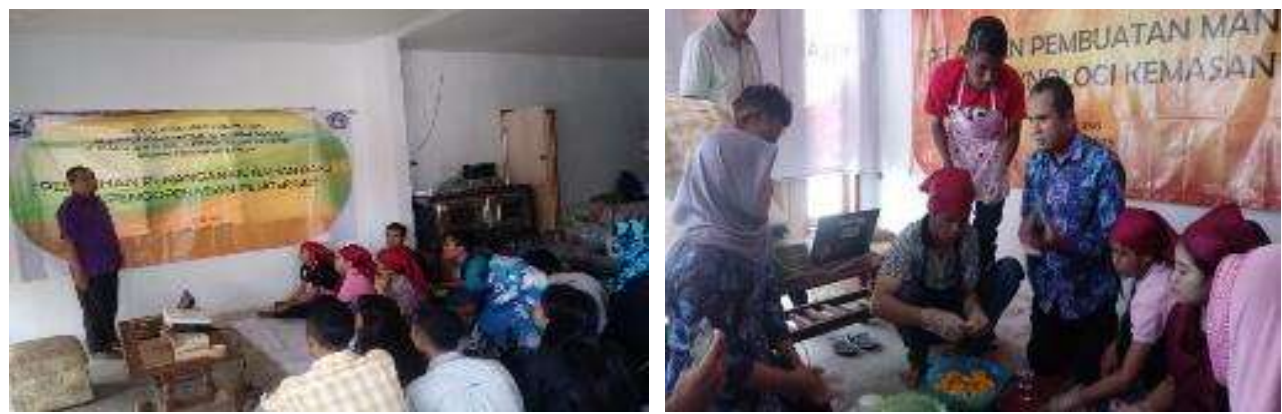

Gambar 2. Pendampingan penanganan bahan baku dan pembuatan manisan nangka kering

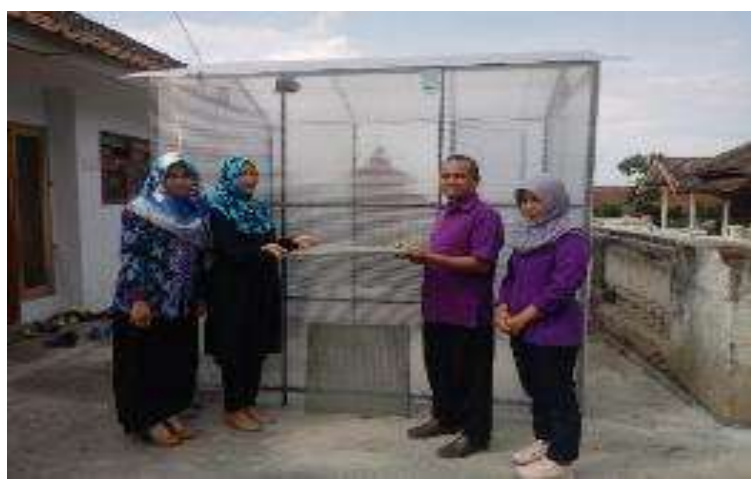

Gambar 3. Proses serah terima rumah kaca kepada CV. Toulip

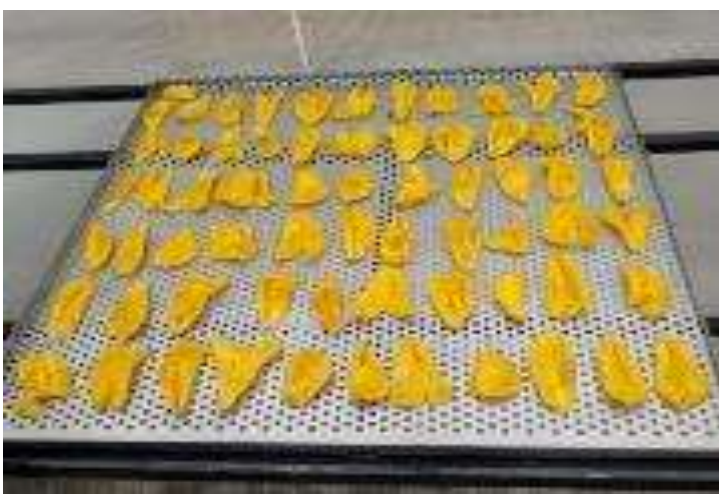

Gambar 4. Produk manisan nangka setelah satu hari pengeringan dengan kualitas sesuai SNI 


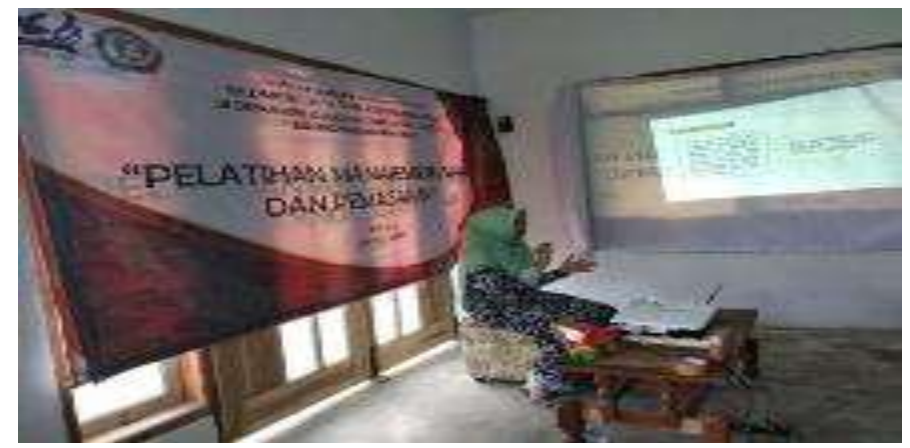

Gambar 5. Pelatihan manajemen usaha dan pemasaran kepada kedua mitra

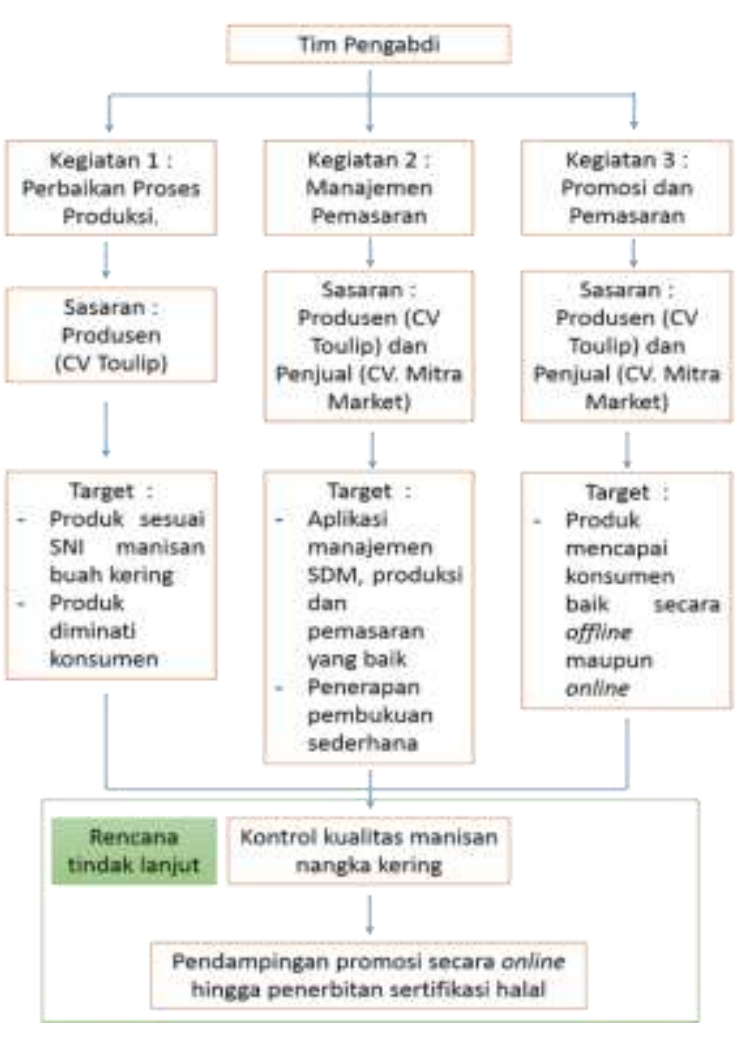

Gambar 6. Rencana tindak lanjut program kemitraan

\section{KESIMPULAN}

Program kemitraan masyarakat dengan melibatkan dua mitra yakni CV. Toulip dan CV. Mitra Market dapat disimpulkan bahwa program pendampingan dalam produksi manisan nangka kering efektif memperbaiki mutu dari manisan buah tersebut. Aplikasi rumah kaca yang dilengkapi dengan exhaust fan dan lampu halogen, menghasilkan manisan nangka kering mengandung kadar air tidak lebih dari $31 \%$ dan memiliki warna kuning cerah. Pelatihan manajemen pemasaran juga menghasilkan perubahan yang signifikan terkait perhitungan kelayakan usaha dalam memproduksi manisan nangka kering. Sebagai tindak lanjut, pendampingan dalam kegiatan promosi secara online, misalnnya dengan pembuatan web promosi terus dilanjutkan.

\section{DAMPAK DAN MANFAAT KEGIATAN}

Uji organoleptik pada manisan nangka kering menunjukkan bahwa panelis menyukai warna dari produk manisan nangka kering yang diproses dengan menggunakan rumah kaca. Produk manisan nangka kering yang browning hampir tidak ditemukan.

Prosentase keberhasilan manisan nangka kering yang tidak mengalami browning sebesar 90\%. Selain itu, rasa dan aroma dari manisan buang kering tersebut juga tidak berkurang. Dampak dari kegiatan adalah meningkatnya keterampilan pembuatan manisan nangka kering. Kelompok usaha tersebut juga mulai meningkatkan produksi manisan nangka kering. Kegiatan promosi dan pemasaran produk manisan nangka kering ini merupakan kegiatan lanjutan dengan melibatkan kedua mitra usaha dengan pihak penggagas program kemitraan masyarakat untuk berkomitmen dalam meneruskan kegiatan produksi manisan nangka kering hingga dapat mencapai target yaitu seluruh lapisan masyarakat.

Adapun skema tindak lanjut digambarkan pada Gambar 6. Baik CV. Toulip maupun CV. Mitra Market sebelumnya telah memiliki distributor dan pelanggan tetap melalui pembukaan gerai di lokasi produksi. Tindak lanjut kedepan adalah pendampingan program 
PKM Kelompok Usaha Pembuatan Manisan Nangka di Desa Selorejo-Kucur Kecamatan Dau Kabupaten Malang Provinsi Jawa Timur

promosi produk untuk dapat dipasarkan keberbagai pasar seperti bazaar, supermarket, pasar dalam bentuk offline maupun online.

\section{DAFTAR PUSTAKA}

1. Fatah, MA,, Bahtiar Y. "Membuat Manisan Buah." Jakarta : PT. Agro Media Pustaka,2004

2. Sediaoetomo, AD. "Ilmu Gizi Jilid II." Jakarta : Dian Rakyat, 2006

3. Sohibulloh, I.,Hidayat Darimiyya, Burhan. "Karakteristik Manisan Nangka Kering dengan Perendaman Gula Bertingkat", Agrointek. Vol, 7 No.2, 2013

4. Badan Pusat Statistik. "Potensi Produksi Buah di Malang Jawa Timur”,2013
5. Rosenthal, AJ. "Food texture : measurement and perception”. Aspen Publishers Inc. Maryland, 1999

6. Buntaran, W., Astirin OP., Mahajoeno, E. "Pengaruh Konsentrasi Larutan Gula Terhadap Karakteristik Manisan Kering Tomat (Lycopersicum esculentum)". Jurnal Bioteknologi Vol. 8 No. 1, (2011):1-9

7. SNI 01-3710-1995 : Syarat mutu manisan buah kering

8. Ruauw, E., Katiandagho, TM, dan Suwardi, PA. 2012. Analisis Keuntungan dan Nilai Tambah Agriindustri Manisan Pala UD Putri di Kota Blitung. ASE Vol. 8 No. 1,(2012):31-44 